Sheffield Hallam

University
Centre for

Regional Economic and Social Research

\title{
Evaluation of Making It Work: An assessment of impact and value for money
}

\section{June 2017}
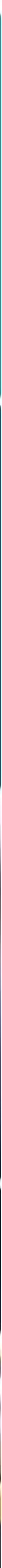


\section{Evaluation of Making It Work: an assessment of impact and value for money}

Author(s):

Chris Dayson

Sarah Pearson

Elizabeth Sanderson

June 2017

DOI: $10.7190 /$ cresr.2017.5337382782 


\section{Contents}

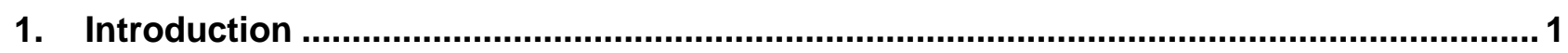

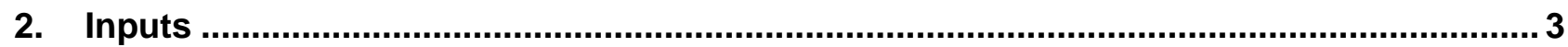

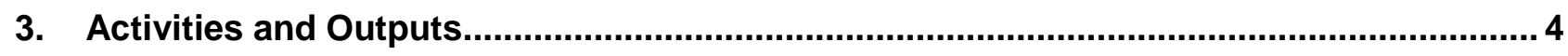

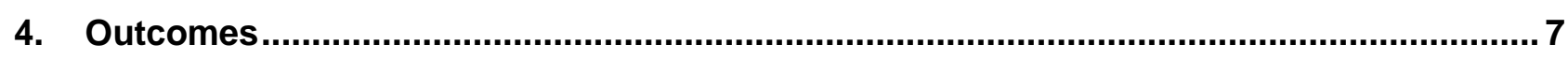

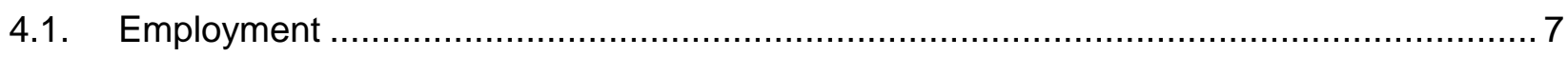

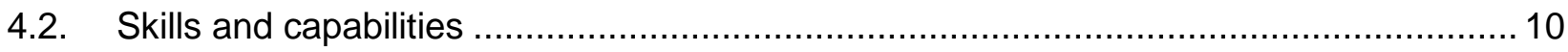

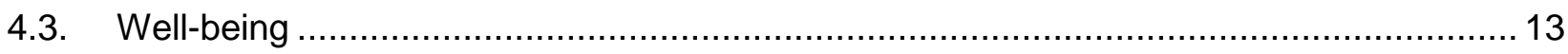

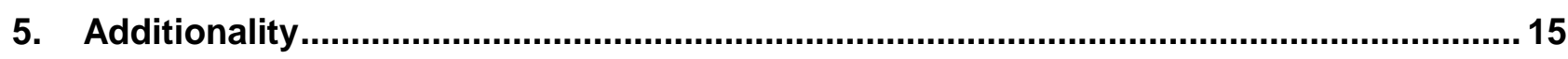

5.1. To what extent are the Making it Work outcomes additional? .................................. 15

6. Benchmarking with other employment support programmes .......................................17

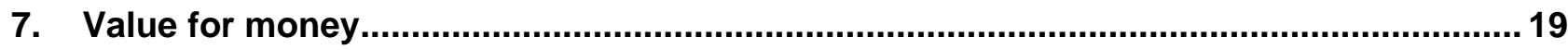

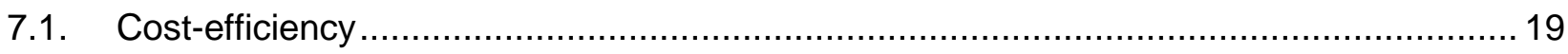

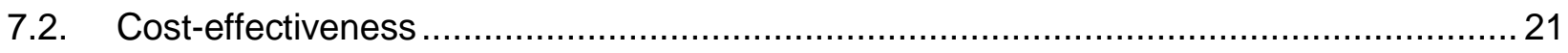

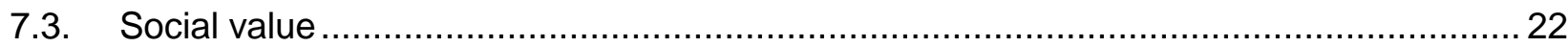

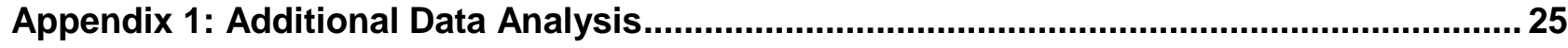

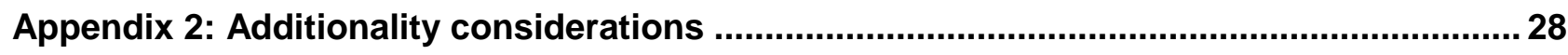




\section{THE IMPACT OF MAKING IT WORK: AN OVERVIEW}

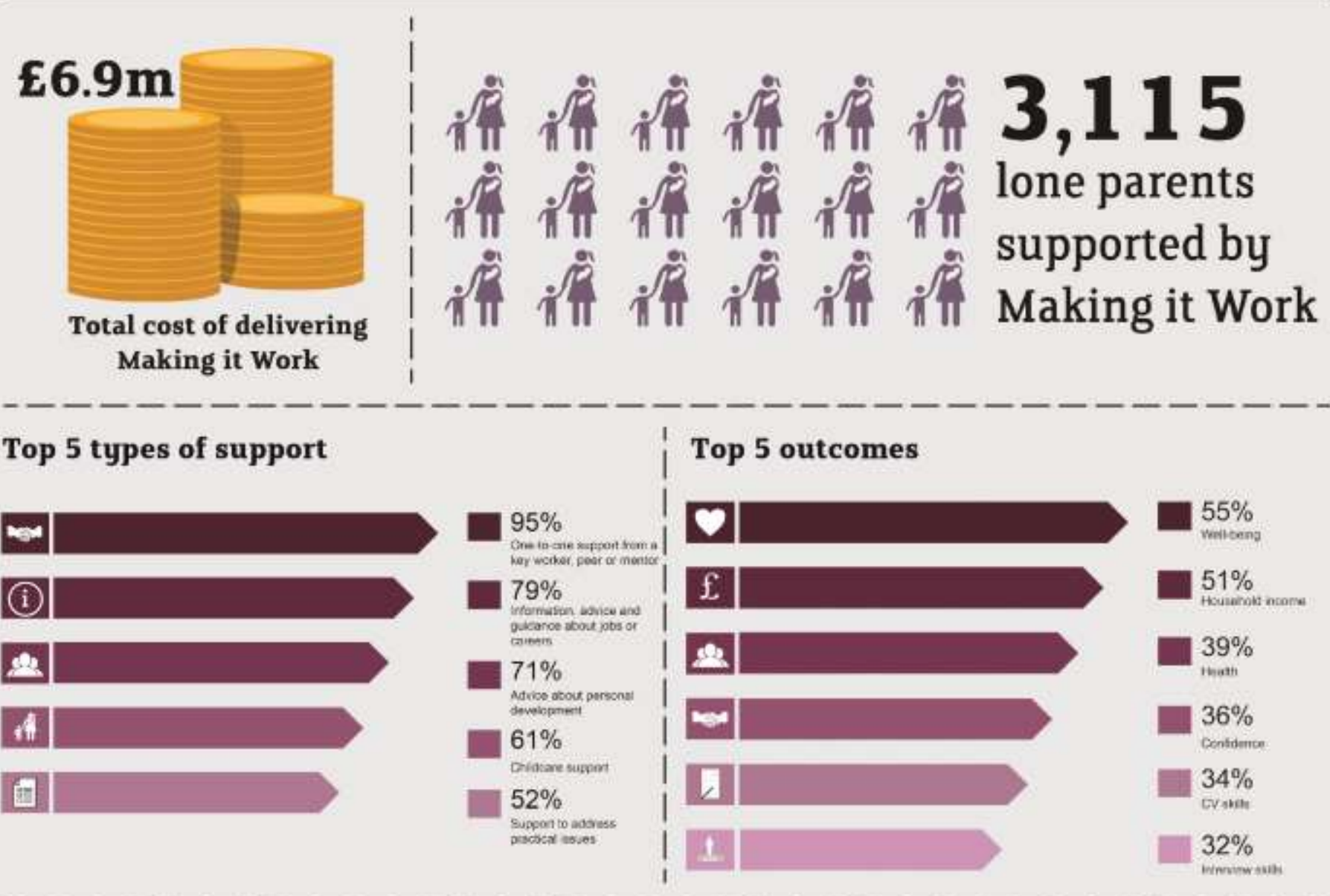

Factors statistically associated with finding employment

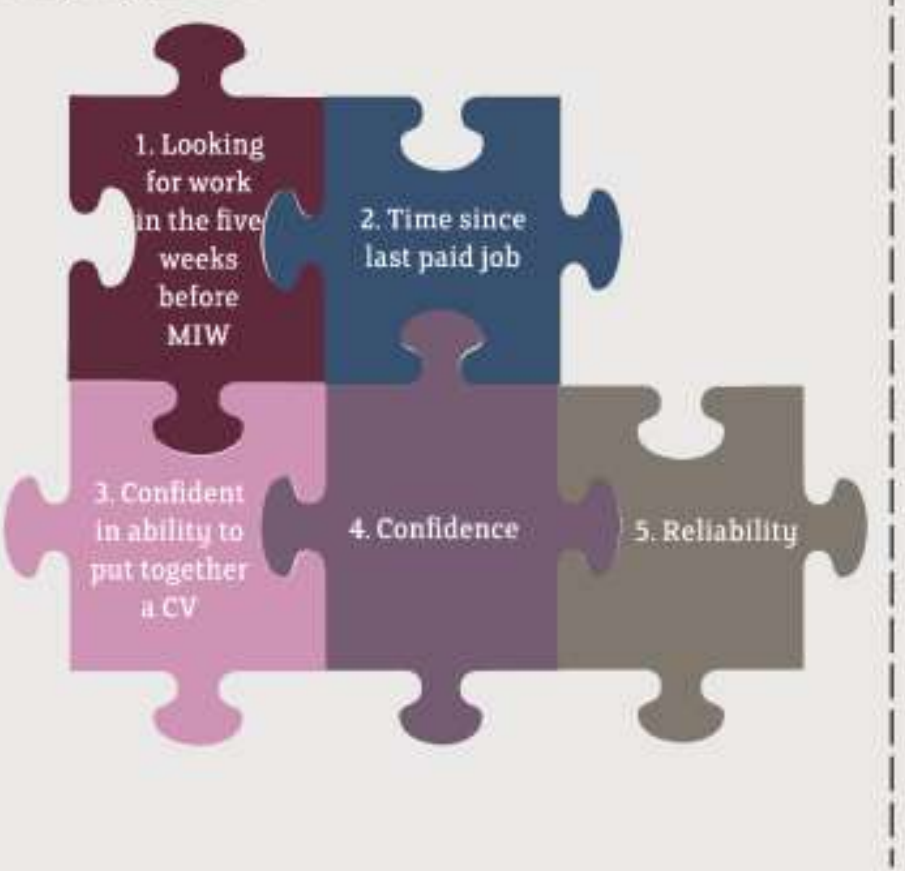

Economic value of lone

The social value of lone parents finding work

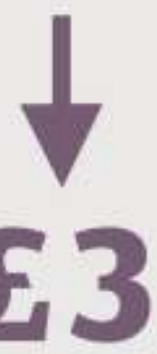

million parents finding work

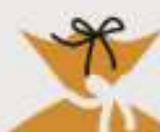

$£ 11.5$ million

\section{5}

Lone parents have found paid work 


\section{Introduction}

Between 2013-017 the Big Lottery Fund (the Fund) in Scotland is investing £7 million in Making it Work (MIW), an innovative programme designed to support lone parents living in complex circumstances. MIW is being delivered by partnerships involving public, private and third sector providers in five local authority areas where there are high concentrations of lone parent families: Edinburgh, Fife, Glasgow, North Lanarkshire and South Lanarkshire.

The overarching objective of MIW is to provide lone parents with intensive support in their journeys toward sustainable employment based on a model of support which includes: signposting and access to existing service provision, key worker support, and ensuring linkages between employability and support services including childcare. It includes the following elements:

- Early engagement: reaching and engaging lone parents.

- Pre-engagement: personal development, planning for work and childcare, improved and accelerated access to provision for lone parents.

- Engagement: access to mainstream provision, supporting lone parents to engage with mainstream providers and ensuring effective access and support.

- Post-employment: support for job retention and progression, and working with employers to encourage family friendly practice.

This report provides a final assessment of impact and value for money of the MIW Programme by exploring a logical chain of costs (inputs) and benefits (activities, outputs and outcomes). This involves a number of stages:

1. Setting out the inputs which enabled MIW to be delivered

2. Mapping the activities and outputs delivered by MIW partnerships

3. Measuring the main outcomes experienced by clients of MIW

4. Considering the additionality and impact of MIW

5. Identifying the return on investment of the MIW programmes

The findings in this report draw on data from a number of sources.

- Annual monitoring returns provided by each partnership using a common template.

- $\quad$ Longitudinal surveys of lone parents engaging with the MIW programme. 
- Qualitative interviews with MIW clients and key stakeholders in the MIW programme.

- A short review of the impact and value for money achieved by a variety of different employment support programmes.

The remainder of this report considers each stage of the logic model in turn, providing data on inputs, activities and outputs and outcomes, before presenting analysis of additionality, impact and overall value for money of the Making It Work programme. 


\section{Inputs}

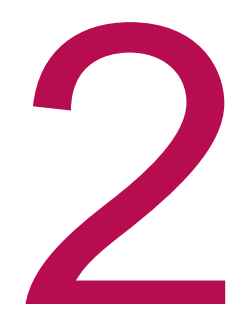

The inputs are the resources necessary to deliver the MIW programme. The majority of the resource for delivering MIW has been provided by the Big Lottery Fund in the form of grants to each of the five partnerships. However, some additional resource was 'levered' in to the programme through additional funding, in kind support, and by utilising volunteers. An overview of these resource inputs is provided in table 1 . It shows that the overall amount of funding provided to deliver MIW between 2013/142016-17 was $£ 6.72$ million but that this was supplement by $£ 14,000$ of additional levered funding and $£ 204,000$ of in-kind support.

Table 1: Costs of delivering the MIW programme (2013/14-2016/17)

\begin{tabular}{lrcrrrr}
\hline & Total & Edinburgh & Fife & Glasgow & S Lanarks & N Lanarks \\
\hline $\begin{array}{l}\text { Total value of MIW } \\
\text { project funding }\end{array}$ & $£ 6.72 \mathrm{~m}$ & $£ 1.13 \mathrm{~m}$ & $£ 1.20 \mathrm{~m}$ & $£ 1.90 \mathrm{~m}$ & $£ 1.25 \mathrm{~m}$ & $£ 1.24 \mathrm{~m}$ \\
$\begin{array}{l}\text { Total value of any } \\
\text { additional funding }\end{array}$ & $£ 0.014 \mathrm{~m}$ & $£ 0.014 \mathrm{~m}$ & - & - & - & - \\
$\begin{array}{l}\text { Total value of in- } \\
\text { kind support in }\end{array}$ & $£ 0.20 \mathrm{~m}$ & $£ 0.15 \mathrm{~m}$ & $£ 0.036 \mathrm{~m}$ & - & $£ 0.016 \mathrm{~m}$ & \\
\hline Total & $£ 6.94 \mathrm{~m}$ & $£ 1.30 \mathrm{~m}$ & $£ 1.24 \mathrm{~m}$ & $£ 1.90 \mathrm{~m}$ & $£ 1.27 \mathrm{~m}$ & $£ 1.24 \mathrm{~m}$ \\
\hline
\end{tabular}

Source: Big Lottery Fund, Partnership level monitoring data

It is important to note that each MIW partnership worked closely with other support providers in their area. This included taking referrals of clients but also referring clients on for additional targeted support. This additional support will have incurred a 'cost' to non-MIW providers that it has not been possible to capture through the evaluation. As such the inputs described here should be considered the direct costs of delivering MIW with any indirect costs excluded from the analysis. 


\section{Activities and Outputs}

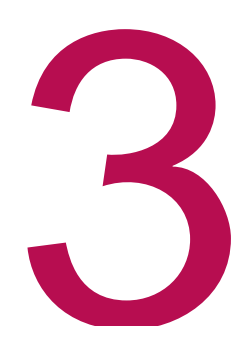

The activities and outputs describe the main deliverables of the MIW programme and provide an insight into the range of services and support available to lone parents in each of the five areas. Table 2 provides an overview of headline outputs reported by MIW partnerships since the programme started.

Table 2: Headline partnership level outputs for the MIW programme (2013/142016/17)

\begin{tabular}{lrrrrrrr}
\hline & Total & Edinburgh & Fife & Glasgow & S Lanarks & N Lanarks \\
\hline $\begin{array}{l}\text { Number of lone parents } \\
\text { supported }\end{array}$ & 3,115 & 422 & 456 & 1,475 & 454 & 308 \\
$\begin{array}{l}\text { Number of referrals-in to } \\
\text { the programme }\end{array}$ & 4,154 & 799 & 456 & 1,475 & 904 & 520 \\
\hline
\end{tabular}

Source: Partnership level monitoring data

Table 2 shows that across the partnerships, 3,115 lone parents received support and 4,154 were referred to the programme for support. Table 3 draws on partnership level monitoring data to illustrate the extent of support provided between 2013/142016/17 across the areas of employment support, training and skills support, personal support, work experience and volunteering, paid work and childcare. It highlights the dual focus of the MIW programme: although the majority of lone parents received employment support through the completion of action plans $(3,161)$, job search activities $(2,119)$ and in-work support $(1,059)$, large numbers also received personal support associated with their personal development $(3,373)$, personal issues (such as health conditions, substance use etc.) $(1,767)$ and practical issues (such as debt, transport, housing etc.) (2,242). In addition, significant numbers of lone parents received training and skills support in the form of basic skills development $(1,766)$ and accredited $(1,104)$ and non-accredited $(609)$ courses and qualifications. Lone parents accessing the MIW programme also had access to funded childcare provision: overall 897 lone parents and 2,396 accessed this provision. Work experience and volunteering was not a core feature of the MIW programme but small numbers of clients did access opportunities in these areas: overall 201 lone parents undertook work experience and 147 engaged in volunteering.

Figure 4 draws on follow-up surveys of MIW clients to provide an overview of the types support that they reported having received through the programme. It highlights how a large majority of clients (95 per cent) received one-to-one support from a key worker, peer or mentor. Other common types of support received included information, advice and guidance about jobs or careers (79 per cent), advice about personal development (71 per cent), childcare support (61 per cent), 
and support to address practical issues (such as debt or housing) (52 per cent). On average MIW clients reported receiving between five and six types of support through the programme.

Table 3: Overview of support activities for $2013 / 14-2016 / 17^{*}$

\begin{tabular}{|c|c|c|c|c|c|}
\hline & Total & $2013 / 14$ & $2014 / 15$ & $2015 / 16$ & $2016 / 17$ \\
\hline \multicolumn{6}{|l|}{ Employment support: } \\
\hline $\begin{array}{l}\text { Number of lone parents } \\
\text { completing action plans }\end{array}$ & 3,161 & 318 & 1,180 & 1211 & 452 \\
\hline $\begin{array}{l}\text { Number of lone parents } \\
\text { undertaking job search activities }\end{array}$ & 2,119 & 544 & 727 & 637 & 211 \\
\hline $\begin{array}{l}\text { Number of lone parents receiving } \\
\text { in-work support }\end{array}$ & 1,059 & 91 & 282 & 441 & 245 \\
\hline \multicolumn{6}{|l|}{ Training and skills support: } \\
\hline $\begin{array}{l}\text { Number of lone parents obtaining } \\
\text { non-accredited training outcomes }\end{array}$ & 609 & 24 & 283 & 176 & 126 \\
\hline $\begin{array}{l}\text { Number of lone parents obtaining } \\
\text { accredited training outcomes }\end{array}$ & 1,104 & 115 & 425 & 348 & 216 \\
\hline $\begin{array}{l}\text { Number of lone parents receiving } \\
\text { basic skills support }\end{array}$ & 1,766 & 198 & 708 & 561 & 299 \\
\hline \multicolumn{6}{|l|}{ Personal support: } \\
\hline $\begin{array}{l}\text { Number of lone parents receiving } \\
\text { personal development support }\end{array}$ & 3,373 & 576 & 1,305 & 979 & 513 \\
\hline $\begin{array}{l}\text { Number of lone parents receiving } \\
\text { support to address personal } \\
\text { issues (health, substance use } \\
\text { etc.) }\end{array}$ & 1,767 & 236 & 836 & 484 & 211 \\
\hline $\begin{array}{l}\text { Number of lone parents receiving } \\
\text { support to address practical } \\
\text { issues (debt, transport, housing) }\end{array}$ & 2,242 & 468 & 1,004 & 534 & 236 \\
\hline \multicolumn{6}{|c|}{ Work experience and volunteering: } \\
\hline $\begin{array}{l}\text { Number of lone parents engaged } \\
\text { in work experience }\end{array}$ & 201 & 15 & 54 & 96 & 36 \\
\hline $\begin{array}{l}\text { Number of lone parents engaged } \\
\text { in volunteering }\end{array}$ & 147 & 17 & 38 & 57 & 35 \\
\hline \multicolumn{6}{|l|}{ Childcare: } \\
\hline $\begin{array}{l}\text { Number of lone parents } \\
\text { accessing MIW funded childcare }\end{array}$ & 897 & - & 656 & 145 & 96 \\
\hline $\begin{array}{l}\text { Number of children of lone } \\
\text { parents accessing MIW funded } \\
\text { childcare }\end{array}$ & 2,396 & - & 921 & 1,357 & 118 \\
\hline
\end{tabular}

Source: Partnership level monitoring data

*Note that for some measures lone parents will have received certain types of support on multiple occasions.

+Data not collected in 2013/14 
Table 7: Types of support received from the Programme overall

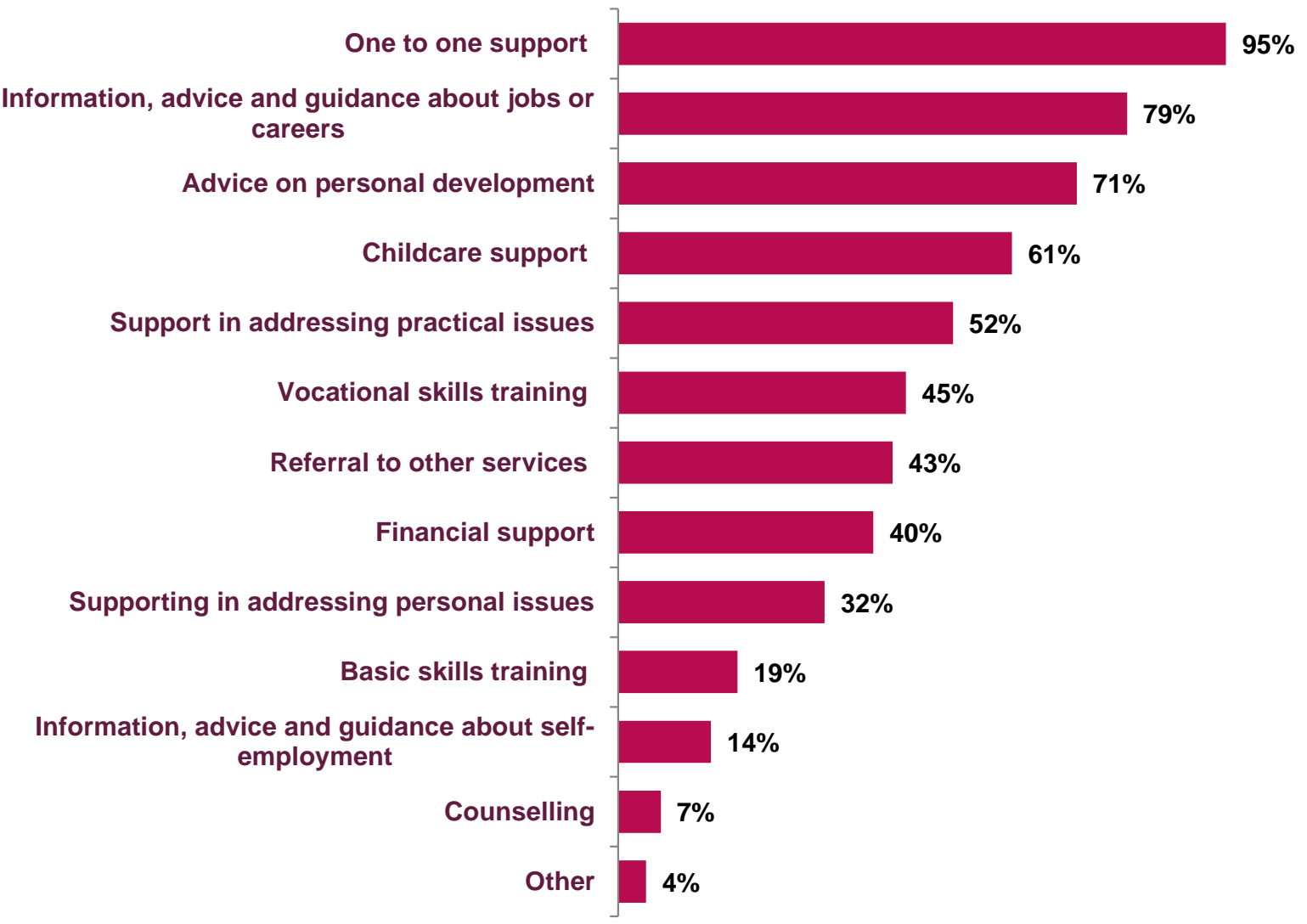

Source: Follow-up survey of MIW clients

Base: 435 


\section{Outcomes}

The outcomes of the MIW programme are the changes experienced by its key stakeholders that could logically have been brought about by the activities and outputs described in the previous section. The focus for this report is three types of outcome for clients (i.e. lone parents) supported by the five MIW partnerships:

- Employment: whether or not lone parents found paid employment following support.

- $\quad$ Skills and capabilities: the skills, confidence and other competencies achieved by lone parents following support.

- Well-being: improvements in the lives of lone parents beyond employment and capabilities following support.

Each of these outcomes is discussed in more detail below.

\subsection{Employment}

Figure 2 provides an overview of employment outcomes for MIW clients at an overall and partnership level. 
Figure 2: MIW employment outcomes by partnership

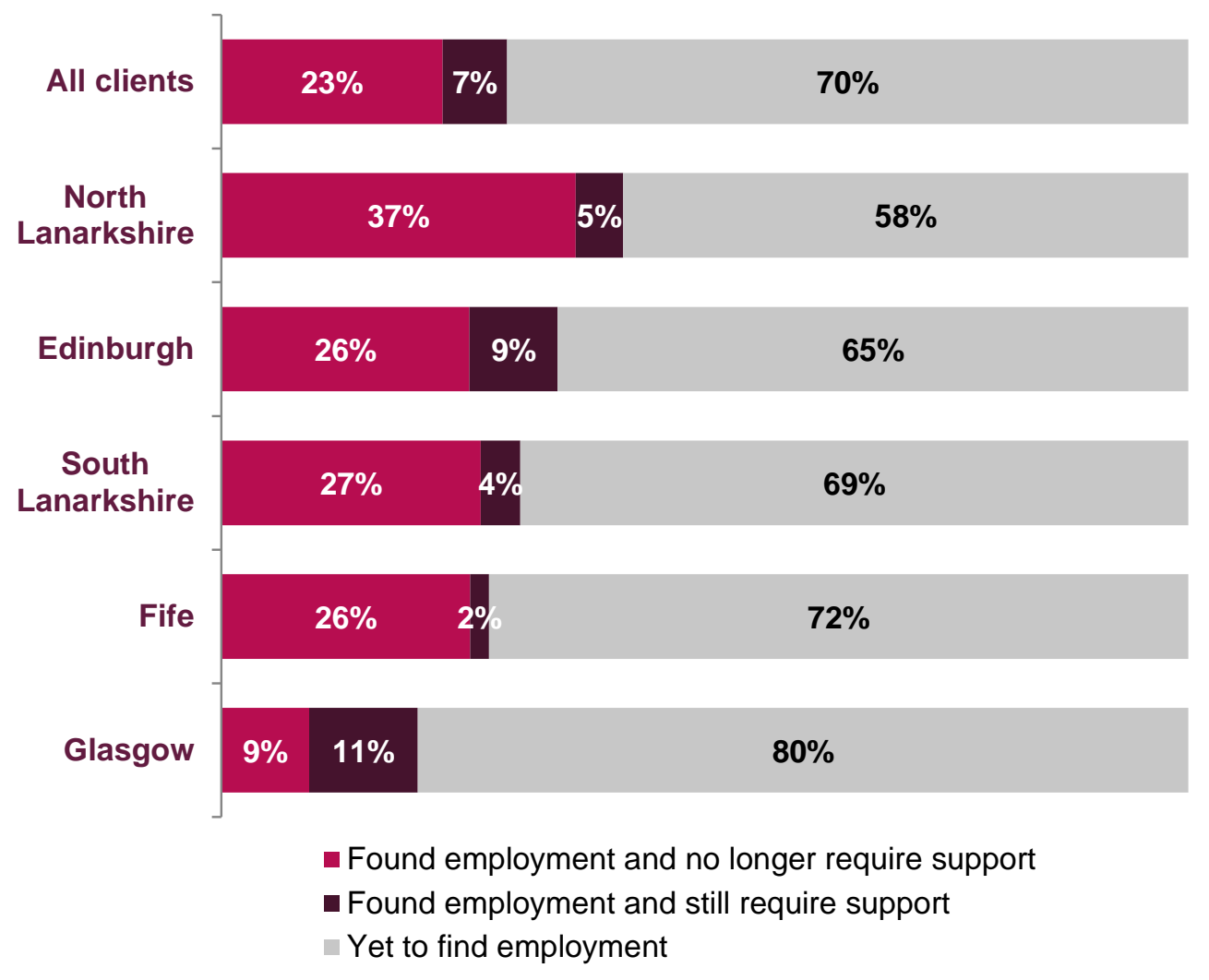

Source: Baseline and follow-up surveys of MIW clients

Base: 1,215

Figure 2 shows that, overall, 30 per cent of MIW clients found paid employment following support from one of the five partnerships. This included 23 per cent who found employment and no longer required support and seven per cent who had found employment but still required support. According to the monitoring data submitted by partnerships, 83 per cent of lone parents who found employment were working more than 16 hours per week and 17 per cent were working less than 16 hours per week.

There was considerable variation by partnership, with 42 per cent of clients supported by the North Lanarkshire partnership finding paid work compared with 35 per cent from Edinburgh, 31 per cent from South Lanarkshire, 28 per cent from Fife and 20 per cent from Glasgow. However, it is important to note that Glasgow support considerably more lone parents than the other partnerships, meaning the total number of clients who found work was greater than some of the other partnerships.

Figures A-E in Appendix 1 provide additional analysis of employment outcomes for MIW clients. They highlight a number of variations:

- $\quad$ Clients with a disability were less likely to have found work: only 23 per cent of lone parents with a disability found employment, falling to 16 per cent for lone parents reporting a disability that 'limited their day to day activities'.

- Clients with a limited employment history and no formal qualifications were less likely to have found work: only 22 per cent of lone parents who had been out work for five years or longer found employment, falling to 18 per cent 
for those who had never had a paid job before. In addition, only 20 per cent of lone parents who had no formal qualifications found employment.

- Clients with caring responsibilities were less likely to have found work: only 28 per cent of lone parents with three or more children had found worked and only 22 per cent of lone parents with additional caring responsibilities had found work.

- Clients with young children found it harder to find work: 34 per cent of lone parents whose young child was aged five or over had found work, falling to 28 per cent whose youngest child was aged between one and four and 26 per cent whose youngest child was aged less than one.

- Clients with poor health and well-being were less likely to have found paid work: only 21 per cent of lone parents who reported poor health (a score of 1-2) and only 17 per cent who reported low well-being (a score of 1-2) had found work.

Additional statistical analysis (logistic regression) was undertaken to identify the factors most strongly associated with finding work. These are highlighted in figure 3 which shows:

1. Having been looking for work in the five weeks prior to engaging with Making it Work was the factor most strongly associated with finding work.

2. Having been out of work for five years or more prior to engaging with Making it Work was the factor with the second strongest association with (not) finding work.

3. Being confident in your ability to put together a CV was the factor with the third strongest association with finding work.

4. Reporting high levels of confidence - including self-esteem, self-belief, selfrespect, self-awareness, and dealing with nerves - was the factor with the fourth strongest association with finding work.

5. Reporting high levels of reliability - including time-keeping, meeting deadlines, taking responsibility, and attendance - was the final factor with a statistical association with finding work. 
Figure 3: Factors with the strongest statistical association with finding employment

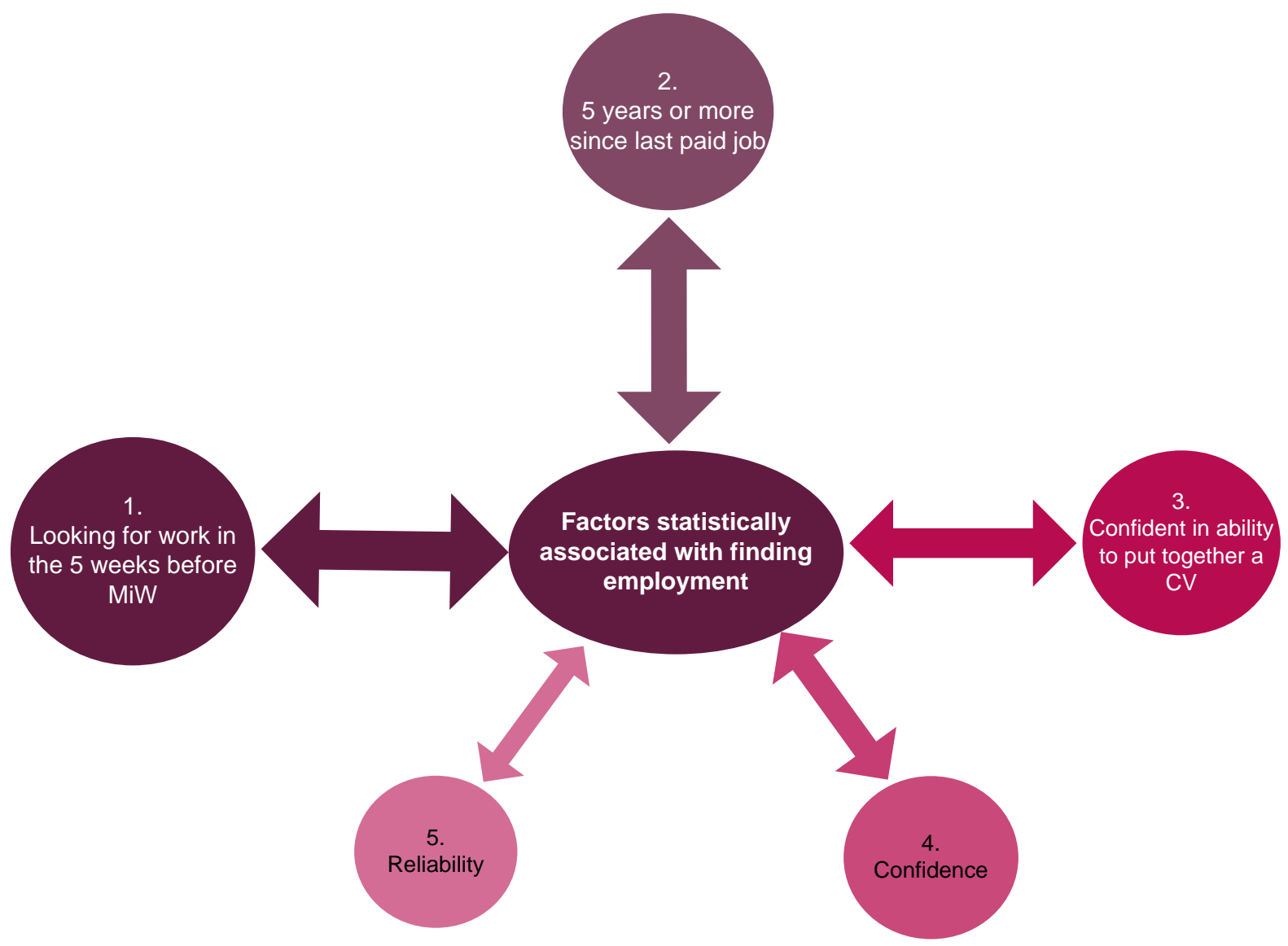

Source: Baseline and follow-up surveys of MIW clients

Base: 1,215

Note: The larger the circle/thicker the line, the stronger the statistical association. Factors ranked 1-5 in order of importance.

Partnership was also strongly associated with finding work, with lone parents in Fife and Glasgow significantly less likely to be in employment than those in Edinburgh and North and South Lanarkshire.

Overall, the importance of these factors highlights the importance of overall 'proximity' to the labour market to the likelihood of finding work. Those lone parents who were 'closest' to the labour market at the point at which they first engaged with Making it Work were most likely to find employment following their engagement with the programme.

\subsection{Skills and capabilities}

Figure 4 demonstrates the progress made by Making it Work clients toward a range of employment related skills outcomes six and 12 months after their first engagement with the programme. Overall, it shows that clients were more likely to make progress than go backwards against the majority of measures but that progress was more likely after six months than 12 months. However, it is important to note that for each measure a majority of participants did not report any change. 
Progress was most pronounced for the following measures:

- The ability to put together a CV: 34 per cent of lone parents had made progress after six months and 24 per cent had made progress after 12 months. In contrast eight per cent of lone parents went backwards after six months and 17 per cent of lone parents went backwards after 12 months.

- The ability to do well in an interview: 32 per cent of lone parents had made progress after six months and 30 per cent had made progress after 12 months. In contrast eight per cent of lone parents went backwards after six months and 12 per cent of lone parents went backwards after 12 months.

- Good skills for the target job: 29 per cent of lone parents had made progress after six months and 25 per cent had made progress after 12 months. In contrast nine per cent of lone parents went backwards after six months and 15 per cent of lone parents went backwards after 12 months.

- Identifying the training needed: 27 per cent of lone parents had made progress after six months and 21 per cent had made progress after 12 months. In contrast 10 per cent of lone parents went backwards after six months and 16 per cent of lone parents went backwards after 12 months.

Although there is consistent evidence of a 'drop-off' in the proportion of clients making progress with employment skills outcomes after 12 months compared to six months, this might in part be explained by the nature of the Making it Work programme and participants' engagement with it. Lone parents who made progress quickly (i.e. after 6 months) were more likely to have left the programme before 12 months, including as a result of finding work, whereas lone parents with more complex support needs were more likely to have stayed with the programme for 12 months or longer.

Figure 5 demonstrates the progress made by Making it Work clients toward a range of employment related capability outcomes six and 12 months after their first engagement with the programme. Similar to figure 4, it shows that clients were more likely to make progress than go backwards against the majority of measures, but unlike the skills measures in figure 4 progress did not appear drop-off significantly after 12 months.

Progress was most pronounced for the following measures:

- Confidence: 36 per cent of lone parents had made progress after six months and 37 per cent had made progress after 12 months. In contrast six per cent of lone parents went backwards after six months and eight per cent of lone parents went backwards after 12 months.

- Managing feelings: 27 per cent of lone parents had made progress after six months and 22 per cent had made progress after 12 months. In contrast 10 per cent of lone parents went backwards after six months and 13 per cent of lone parents went backwards after 12 months.

- $\quad$ Setting and achieving goals: 25 per cent of lone parents had made progress after six months and 25 per cent had made progress after 12 months. In contrast seven per cent of lone parents went backwards after six months and 10 per cent of lone parents went backwards after 12 months.

- Communication: 21 per cent of lone parents had made progress after six months and 23 per cent had made progress after 12 months. In contrast seven per cent of lone parents went backwards after six months and 10 per cent of lone parents went backwards after 12 months. 
Figure 4: MIW clients' progress on employment related skills outcomes

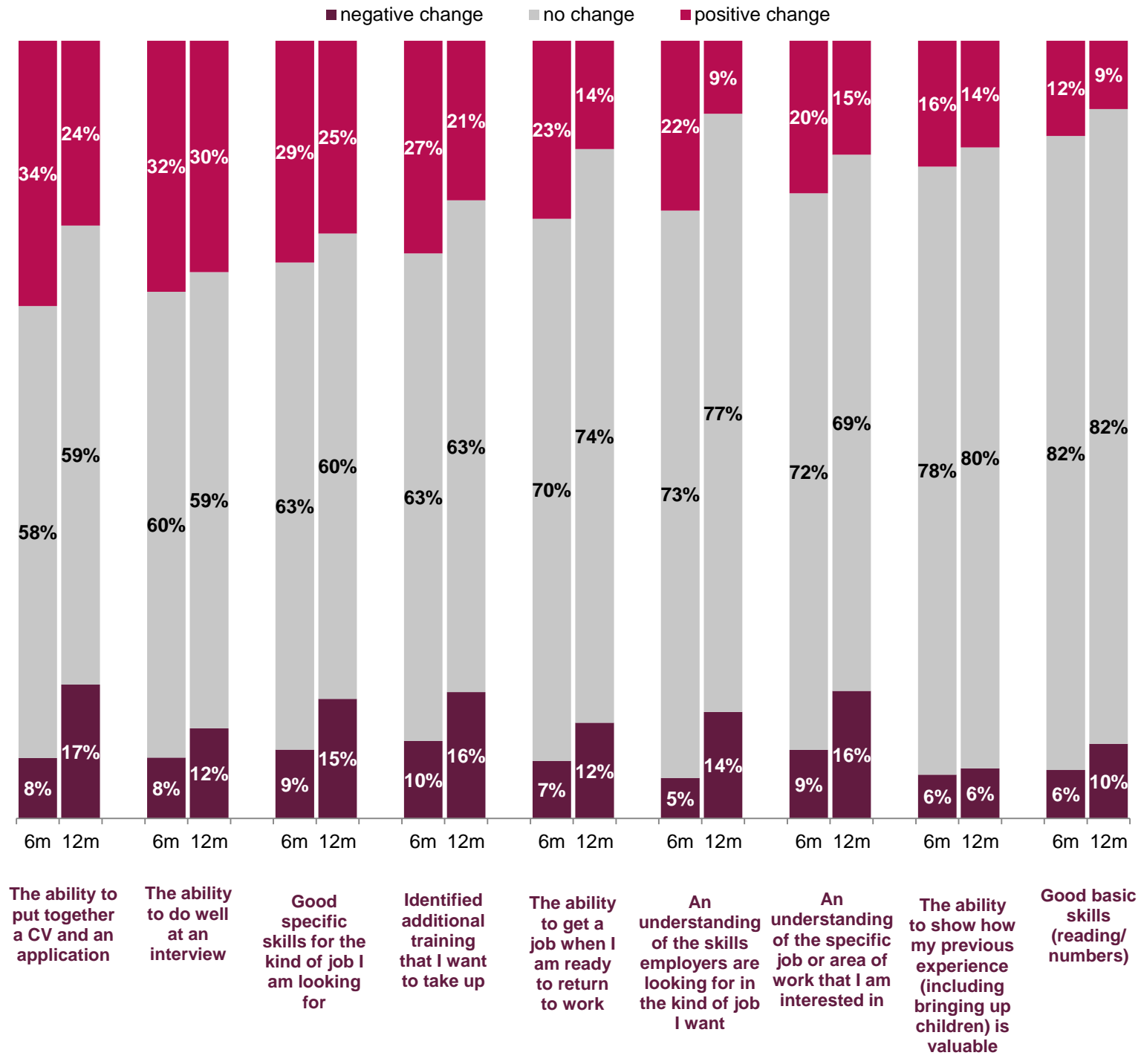

Source: Baseline and follow-up surveys of MIW clients Min. base: 396 (6 months); 116 (12 months) 
Figure 5: MIW clients' progress on employment related capability outcomes

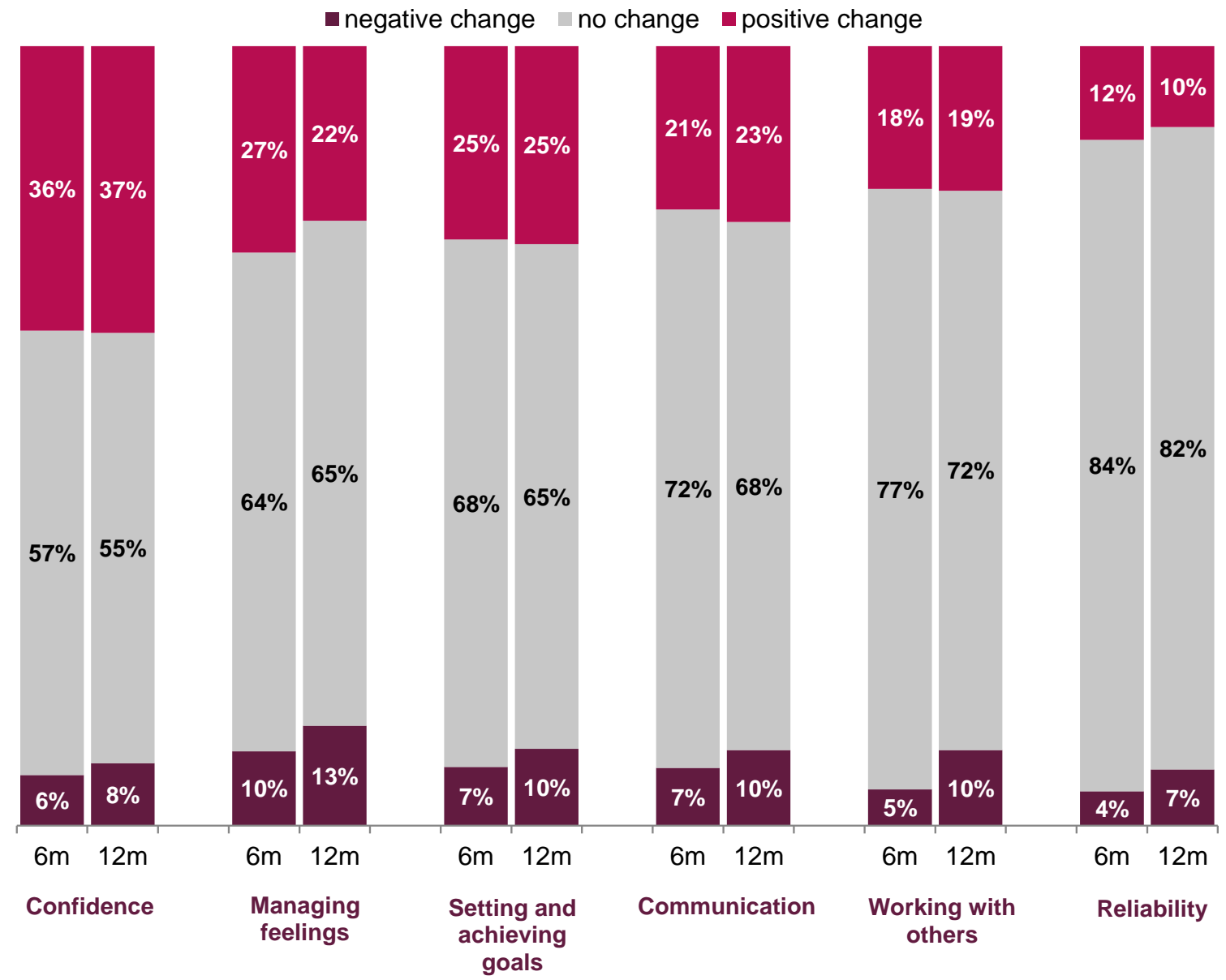

Source: Baseline and follow-up surveys of MIW clients Min. base: 427 (6 months); 122 (12 months)

\subsection{Well-being}

Figure 6 demonstrates the progress made by Making it Work clients toward three measures of health and well-being outcomes six and 12 months after their first engagement with the programme. Similar to skills and capabilities, it shows that clients were more likely to make progress than go backwards against the majority of measures, but progress did appear to drop-off - for health in particular - after 12 months.

- Health: 39 per cent of lone parents made progress after six months, including 17 per cent who made progress of two points or more (on a seven point scale); 32 per cent of lone parents made progress after 12 months, including 17 per cent who made progress of two points or more. In contrast 27 per cent of lone parents went backwards after six months and 41 per cent of lone parents went backwards after 12 months.

- Household income: 51 per cent of lone parents made progress after six months, including 24 per cent who made progress of two points or more; 41 per cent of lone parents made progress after 12 months, including 22 per cent who made progress of two points or more. In contrast 24 per cent of lone parents went backwards after six months and 28 per cent of lone parents went backwards after 12 months. 
- Life overall: 55 per cent of lone parents made progress after six months, including 27 per cent who made progress of two points or more; 47 per cent of lone parents made progress after 12 months, including 23 per cent who made progress of two points or more. In contrast 16 per cent of lone parents went backwards after six months and 28 per cent of lone parents went backwards after 12 months.

Figure 6: MIW clients' progress on health and well-being outcomes

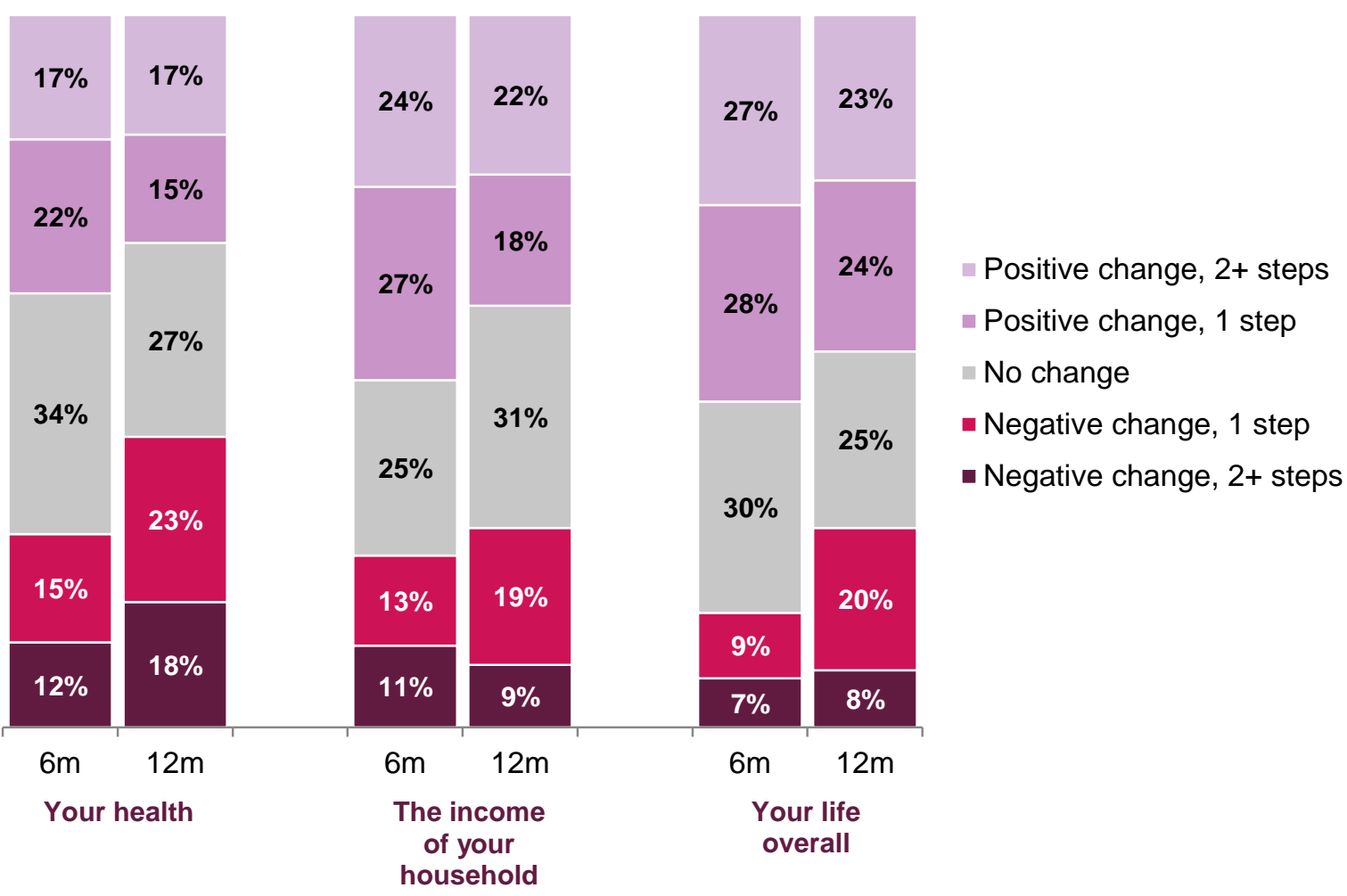

Source: Baseline and follow-up surveys of MIW clients Base: 435 (6 months); 125 (12 months)

Similar to employment skills, the evidence of a 'drop-off' in the proportion of clients making progress with health and well-being outcomes after 12 months compared to six months might in part be explained by the nature of the Making it Work programme and participants' engagement with it. Lone parents whose initial levels of health and well-being were more positive were more likely to have left the programme before 12 months, including as a result of finding work, whereas lone parents with more complex health and well-being needs were more likely to have stayed with the programme for 12 months or longer. 


\section{Additionality}

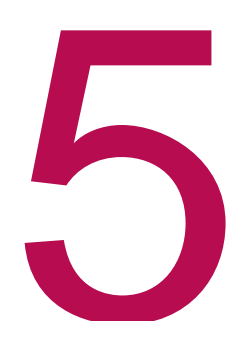

When assessing the value for money and impact of an intervention it is important to consider the principle of additionality: the extent to which the outcomes reported should be attributed to the intervention being evaluated. It involves considering three factors: leakage, deadweight, displacement and substitution. We address each of these in Appendix 2, with a summary of the key findings provided below.

\subsection{To what extent are the Making it Work outcomes additional?}

Overall, the qualitative data paints a positive picture of the importance of the Making it Work interventions. Lone parents' testimonies in particular reveal the significance and value of the support they received from the partnerships. The support provided to clients throughout their journey towards employment was seen as crucial to enable the development of softer skills such as confidence, self-esteem and familial relationships to enabled lone parents move into employment, or feel more ready to find employment in the future. In addition to supporting job outcomes, these softer skills were reported by lone parents to be crucial to family- and work-life balance and to delivering improved well-being for themselves and their children. The personcentred 'wrap around package' of support provided by the programme based on long-term supportive relationships with key workers and the development of peer support set Making it Work apart from other employment support programmes, including the Work Programme.

Drawing on these qualitative insights, in combination with the survey and monitoring data presented in previous sections, a number of inferences about the additionality of key outcomes associated with the Making it Work programme can be made.

\section{Proximity to the labour market}

The survey data highlights the importance of proximity to the labour market for whether or not Making it Work clients found work. There is strong evidence that lone parents who were closest to the labour market when they first engaged with the programme - those who were already actively looking for work and had relatively recent experience of work - were most likely to find work in period that followed. This suggests that the likelihood many of these lone parents would have found work eventually without the support from Making it Work is quite high.

\footnotetext{
${ }^{1}$ These findings are discussed in more detail in the Making it Work final evaluation report.
} 


\section{Moving lone parents closer to the labour market}

There is evidence that Making it Work has been effective in supporting lone parents to move closer to the labour market. For example, reporting high levels of confidence was the employment capability with the strongest association with finding work and also the measure with the greatest amount of improvement after six and 12 months, with more than a third of lone parents making progress at each time point. Similarly looking for work was the factor with the strongest association with finding work overall, and the monitoring data from the partnerships shows that more than two-thirds of clients were supported to undertake job search activities. This suggests that for lone parents who were furthest from the labour market Making it Work has played an important role in helping better equipped to find work, meaning any subsequent employment outcomes for this group will have much higher levels of additionality than for lone parents who were much closer to the labour market from the outset.

\section{Achieving soft outcomes}

The qualitative evidence demonstrated the important role of Making it Work partnerships providing lone parents with personally tailored packages of support that were not available from other providers in their area. This evident in the soft outcomes achieved by many lone parents in areas such as the practical skills needed to find employment; key capabilities such as confidence, managing feelings and communication; and broader outcomes associated with health and well-being. As lone parents had limited opportunities to access this type of support from other sources the additionality associated with these soft outcomes is likely to be relatively high.

The overall inference from the evaluation findings is that additionality of the Making it Work programme is likely to have varied significantly for different types of clients across different types of outcomes. For employment outcomes, particularly those for lone parents closest to the labour market additionality is likely to be relatively low. However, where employment outcomes have been achieved for lone parents distanced from the labour market additionality is likely to be quite high. Similarly, for soft outcomes, including those associated with moving lone parents closer to the labour market, Making it Work interventions were much more important and highly additional. 


\section{Benchmarking with other employment support programmes}

It is important to set the employment outcomes achieved by Making it Work in the context of other employment support programmes. Although direct comparisons with other programmes should be made with some degree of caution due to differing service delivery models and evaluation methodologies, it is possible to compare the employment outcomes of Making it Work with a number of other programmes. Table 4 provides an overview of employment progression rates from a range of other employment support programmes. It shows that employment progression of between 20-40 per cent of participants had been achieved by the projects reviewed, meaning that 30 per cent progression rate achieved by Making it Work is within the bounds of what would have been expect of this type of project.

Table 4: Overview of employment progression rates from other programmes

\begin{tabular}{|c|c|}
\hline Project & Employment progression rate \\
\hline Evaluation of Want to Work ${ }^{2}$ & 41 per cent entered work of at least 16 hours per week \\
\hline South West Workways ${ }^{3}$ & 35 per cent entered work of at least 16 hours per week \\
\hline $\begin{array}{l}\text { Volunteering for Stronger } \\
\text { Communities }\end{array}$ & $\begin{array}{l}22 \text { per cent found paid work after receiving support, of whom } \\
66 \text { per cent attributed it to the project }\end{array}$ \\
\hline $\begin{array}{l}\text { Evidence review of ESF } \\
\text { Programmes supporting those } \\
\text { furthest from the labour market }\end{array}$ & $\begin{array}{l}\text { Employment rates increased from } 13 \text { per cent on entry to } 33 \\
\text { per cent after } 6-12 \text { months }\end{array}$ \\
\hline \multirow[t]{2}{*}{ ESF Cohort Survey: Wave $3^{6}$} & $\begin{array}{l}\text { Employment rate amongst } \mathrm{P} 1 \text { participants rose from } 6 \text { per } \\
\text { cent for the week prior to } 32 \text { per cent at wave } 3(18-24 \\
\text { months) }\end{array}$ \\
\hline & $\begin{array}{l}\text { Employment rate amongst P4 participants rose from } 4 \text { per } \\
\text { cent for the week prior to } 34 \text { per cent at wave } 3(18-24 \\
\text { months) }\end{array}$ \\
\hline Working for Families ${ }^{7}$ & $\begin{array}{l}15 \text { per cent entered work after receiving support from the } \\
\text { programme }\end{array}$ \\
\hline
\end{tabular}

2 See Riley, T et al (2013). Evaluation of Want to Work. London: CESI

3 See Riley, T et al (2013). South West Workways project evaluation. London: CESI

4 See Bashir, N et al (2013). Final evaluation of the Volunteering for Stronger Communities programme. Sheffield:

Centre for Regional Economic and Social Research

5 See Crisp, R et al (2009). Evidence Review of the impact of ESF on those furthest from the labour market (2007-13). London: Third Sector European Network

6 See Anderson, T et al (2011). European Social Fund Cohort Survey: Wave 3. DWP Research report No 771

${ }^{7}$ See McQuaid et al (2008) Evaluation of the Working for Families Fund (2004-2008), Scottish Government

Social Research 
Importantly, the evidence reviewed also suggests that employment progression is lower amongst hard to reach groups, including those furthest from the labour market and/or facing multiple disadvantage. For example, the South West Workways evaluation found that:

- Participants without a disability (47\%) were more likely to have found work than those with a disability (36\%).

- $\quad$ Participants with Level 2 qualifications or above (52\%) were more likely to have found work than those below Level 2 (35\%).

This also provides some validation for the Making it Work evaluation findings, which show lower rates of employment progression for lone parents with a disability, low levels of self-reported health, and without formal qualifications.

There is limited evidence available on the sustainability of job outcomes achieved through Making it Work. Qualitative data suggests that the emphasis on personalised, holistic and sustained support provided through Making it Work was important in helping lone parents to achieve appropriate and sustainable job outcomes but it has not been possible through this evaluation to track the duration of job outcomes for those lone parents moving into work. Caution should therefore be employed in comparing Making it Work outcomes with those for other employment support programmes where evidence on the sustainability of job outcomes is available. 


\section{Value for money}

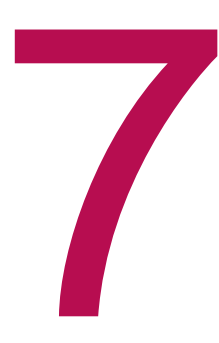

This section considers the value for money of the Making it Work programme by comparing the costs of the delivering the programme with various outputs and outcomes reported earlier in this report. It focusses in turn on cost-efficiency, costeffectiveness and social value.

\subsection{Cost-efficiency}

The cost-efficiency of the Making it Work programme can be assessed through the cost of achieving outputs and outcomes in terms of employment and skills. A first step in the process is to estimate the total number of employment and skills outputs and outcomes experienced by MIW beneficiaries. A summary of key outputs is provided in table 5. Note that the survey data is used as the basis for an extrapolated estimate for the total number of beneficiaries experiencing an output or outcome. This assumes that the survey respondents are representative of MIW beneficiaries as a whole.

Table 5: Overview of employment and skills outputs/outcomes (2013/142016/17)

Estimated number of MIW Beneficiaries

Number

Data source

Jobs

Number of lone parents gaining employment (less than 16 hours)

159 Survey/Monitoring data

Number of lone parents gaining employment (more than 16 hours)

776 Survey/Monitoring data

Total number of lone parents gaining employment

935 Survey/Monitoring data

\section{Skills/Training}

Number of lone parents with a training outcome (non-accredited) 
This shows that overall, it is estimated that 935 lone parents found paid employment, of whom 776 found full-time work (more than 16 hours) and 159 found part-time work (less than 16 hours). It also shows that 1,104 lone parents gained accredited training outcomes and 609 gained non-accredited training outcomes. These outputs and outcomes can be compared with the costs of delivering the Making it Work programme to provide an estimate of cost-efficiency (cost per output/outcome), as shown in table 6.

This indicates that the estimated cost per employment outcome for the whole of the Making it Work programme is $£ 7,424$ (full or part-time employment), the cost per accredited skills outcome is $£ 6,284$ and the cost per non-accredited skills outcome is $£ 11,392$.

Table 6: Cost per employment and skills output/outcome (2013/14-2016/17)

\begin{tabular}{lc}
\hline & \multicolumn{1}{c}{$\begin{array}{c}\text { Cost per } \\
\text { output/outcome }\end{array}$} \\
\hline Jobs & $£ 43,672$ \\
\hline $\begin{array}{l}\text { Number of lone parents gaining employment } \\
\text { (less than } 16 \text { hours) }\end{array}$ & $£ 8,945$ \\
$\begin{array}{l}\text { Number of lone parents gaining employment } \\
\text { (more than } 16 \text { hours) }\end{array}$ & $£ 7,424$ \\
Total number of lone parents gaining employment & $£ 11,392$ \\
\hline Skills/Training & $£ 6,284$ \\
\hline $\begin{array}{l}\text { Number of lone parents with a training outcome } \\
\text { (non-accredited) }\end{array}$ & $\begin{array}{l}\text { Number of lone parents with a training outcome } \\
\text { (accredited) }\end{array}$ \\
\hline
\end{tabular}

An overview of the cost per employment outcome from a range of other employment support programmes is provided in table 7 . These suggest that the value for money of MIW (in terms of employment outcomes) is within the range expected of employment programmes: a regeneration and poverty evidence review ${ }^{8}$ found cost per employment outcomes ranged from $£ 7,400-£ 19,400$, with an average of $£ 13,320$. They also suggest that Making it Work has provided better value for money than some government funded programmes: the cost per employment outcomes are broadly equivalent those associated with the Flexible New Deal ( $₹ 7,495$ per job), and Employment Zones (£7,857 per job) but higher than the New over Deal for Young People/25 plus ( $£ 3,321$ per job). The cost per employment outcome is also within the broad range achieved by other voluntary sector led programmes for which evidence is available. However, it should be noted that none pf these programmes provide a direct comparison: there are differences in terms of programme aims and delivery models, client groups and methods for calculating the number of outcomes, and as outlined earlier these calculations do not take into account the sustainability of job outcomes.

\footnotetext{
${ }^{8}$ Crisp, R et al (2013). Regeneration and poverty: evidence and policy review. Sheffield: Centre for Regional Economic and Social Research
} 
Table 7: Overview of costs per participant of other programmes with employment outcome

\begin{tabular}{lr}
\hline Project & Cost per employment outcome \\
\hline UK and Scottish Government programmes: & \\
\hline Flexible New Deal & $£ 7,495$ \\
Employment Zones & $£ 7,857$ \\
New Deal for Young People/25 plus & $£ 3,321$ \\
Working for Families & $£ 12,342$ \\
\hline Voluntary and community sector led programmes: & \\
\hline Volunteering for Stronger Communities & $£ 4,051$ per net additional employment outcome \\
Bolsover Working Neighbourhoods Fund & $£ 16,492-£ 25,364$ per participant finding work \\
\hline Reviews: & \\
\hline Regeneration and Poverty Evidence Review & An average of $£ 13,320(£ 7,400-£ 19,400$ range) \\
\hline
\end{tabular}

\subsection{Cost-effectiveness}

The cost-effectiveness of Making it Work can be estimated by calculating the value of job and skills outputs/outcomes and the return on investment associated with them. This requires identifying appropriate financial proxies and appending these to the output/outcome figures. Different types of financial proxy can be used to capture different aspects of benefit value. For example:

- Fiscal benefits: describe the direct and indirect savings to the public sector associated with the output/outcome.

- Economic benefits: measure the overall value to society and includes net growth in the local economy allowing for deadweight, leakage and wider social benefits such as improvements to health; educational attainment; access to transport or public services; safety; or reduced crime.

The financial proxies used to value employment and skills benefits are provided in table 7 , with the result of applying these proxies to the MIW output/outcome data presented in table 8. These shows that the majority of the fiscal and economic value associated with Making it Work is created by lone parents gaining employment (more than 16 hours) rather skills and training outcomes ${ }^{9}$ :

- Employment: the total (gross) fiscal value associated with lone parents gaining employment was £8 million; the total (gross) economic value associated with lone parents gaining employment was $£ 11.5$ million.

- $\quad$ Skills and training: the total (gross) fiscal value associated with lone parents gaining accredited training outcomes was $£ 99,000$; the total (gross) economic value associated with lone parents gaining accredited training outcomes was $£ 533,000$.

\footnotetext{
${ }^{9}$ When interpreting these estimates it is important to note a number of important caveats:

- The values reported are gross not net: they do not include an assessment of additionality as there is not sufficiently robust quantitative data to estimate it with any accuracy. As discussed in the earlier section on additionality, this is likely to vary significantly by service user based on their initial 'distance' from the labour market.

- Benefits are only reported for one year: the majority of evaluation data does not extend beyond 12 months following the initial MIW intervention so it is not possible to estimate the extent to which benefits last beyond one year.
} 
Table 7: Financial proxies ${ }^{10}$ for MIW outputs/outcomes (2013/14-2016/17)

\begin{tabular}{|c|c|c|c|}
\hline & Measure & $\begin{array}{l}\text { Fiscal } \\
\text { value }\end{array}$ & $\begin{array}{r}\text { Economic } \\
\text { value }\end{array}$ \\
\hline \multicolumn{4}{|l|}{ Jobs } \\
\hline $\begin{array}{l}\text { Number of lone parents gaining } \\
\text { employment (more than } 16 \text { hours) }\end{array}$ & $\begin{array}{l}\text { Job Seeker's Allowance - } \\
\text { annual fiscal and economic } \\
\text { benefit from a workless } \\
\text { claimant entering work }\end{array}$ & $£ 10,321$ & $£ 14,790$ \\
\hline \multicolumn{4}{|l|}{ Skills/Training } \\
\hline $\begin{array}{l}\text { Number of lone parents with a training } \\
\text { outcome (accredited) }\end{array}$ & $\begin{array}{l}\text { NVQ Level } 2 \text { Qualification - } \\
\text { annual fiscal and economic } \\
\text { benefits }\end{array}$ & $£ 90$ & $£ 483$ \\
\hline
\end{tabular}

Table 8: Fiscal and economic value for each MIW outputs/outcomes (2013/142016/17)

\begin{tabular}{lrr}
\hline & $\begin{array}{r}\text { Gross } \\
\text { Fiscal value }\end{array}$ & $\begin{array}{r}\text { Gross } \\
\text { Economic value }\end{array}$ \\
\hline Jobs & & \\
$\begin{array}{l}\text { Number of lone parents gaining } \\
\text { employment (more than 16 hours) }\end{array}$ & $£ 8,005,329$ & $£ 11,471,642$ \\
\hline Skills/Training & & $£ 533,232$ \\
\hline $\begin{array}{l}\text { Number of lone parents with a training } \\
\text { outcome (accredited) }\end{array}$ & $£ 99,360$ & \\
\hline
\end{tabular}

\subsection{Social value}

The social value of Making it Work can estimated by placing a monetary value on the non-fiscal and non-economic benefits associated with the programme, focussing in particular on outcomes associated with well-being. The approach to valuing wellbeing used here draws on work undertaken by the New Economics Foundation and New Economy Manchester ${ }^{11}$ to value the non-fiscal and non-economic benefits associated with social interventions. In this approach, personal well-being is equated with mental health and an economic value is applied (calculated using a willingness to pay value for the QALY impact of depression ( $\$ 35,400$ per annum)) across four domains: confidence and self-esteem, positive functioning, emotional well-being, and social isolation. However, it is important to note that measurement of subjective wellbeing is a relatively new discipline, and there have been few attempts to value wellbeing. In particular, it is recognised that using mental health as a proxy for well-being may not be the most accurate way of determining its true value. As such the findings presented here should be considered experimental.

From the longitudinal survey of lone parents it was possible to identify three measures for which there were appropriate personal well-being proxy values in the New Economy Manchester Unit Cots Database. These are summarised in table 9

10 The financial proxies used in this analysis are based on the New Economy Unit Cost Database: http://neweconomymanchester.com/stories/1966-cost benefit analysis

11 Cox, J et al (2012) Social Value: Understanding the wider value of public policy intervention. New Economy Working Paper 008. 
followed by an estimate of the social value gained per lone parent and total social value gained in table 10 .

Table 9: Financial proxies for estimating social (well-being) value

\begin{tabular}{|c|c|c|}
\hline Measure & \multicolumn{2}{|c|}{$\begin{array}{l}\text { Financial proxy: full social } \\
\text { value per lone parent }\end{array}$} \\
\hline $\begin{array}{l}\text { Number of lone parents reporting increased confidence/self- } \\
\text { esteem }\end{array}$ & & $£ 3,500$ \\
\hline $\begin{array}{l}\text { Number of lone parents reporting improved positive functioning } \\
\text { (autonomy, control, aspirations) }\end{array}$ & & $£ 3,500$ \\
\hline \multicolumn{2}{|l|}{ Number of lone parents reporting improved emotional well-being } & $£ 3,500$ \\
\hline \multirow[b]{2}{*}{ Measure } & \multicolumn{2}{|c|}{ Social value gained } \\
\hline & $\begin{array}{l}\text { Per lone } \\
\text { parent }\end{array}$ & Total \\
\hline $\begin{array}{l}\text { Number of lone parents reporting increased confidence/self- } \\
\text { esteem }\end{array}$ & $£ 526$ & $£ 1,639,736$ \\
\hline $\begin{array}{l}\text { Number of lone parents reporting improved positive functioning } \\
\text { (autonomy, control, aspirations) }\end{array}$ & $£ 235$ & $£ 732,648$ \\
\hline Number of lone parents reporting improved emotional well-being & $£ 207$ & $£ 645,428$ \\
\hline Total & $£ 969$ & $£ 3,017,812$ \\
\hline
\end{tabular}

Source: Baseline and follow-up surveys of MIW clients

Base: 125 (12 months)

These estimates suggest that, using this methodology, there is considerable social value associated with the well-being benefits experienced by lone parents engaging with the Making it Work programme ${ }^{12}$ :

- Confidence and self-esteem: the total (gross) social value associated with lone parents reporting increased confidence and self-esteem was £1.64 million; this equates to $£ 526$ per lone parent supporting by the programme.

- Positive functioning: the total (gross) social value associated with lone parents reporting improved positive functioning was $£ 0.73$ million; this equates to £235 per lone parent supporting by the programme.

- Emotional well-being: the total (gross) social value associated with lone parents reporting improved emotional well-being was $£ 0.65$ million; this equates to £207 per lone parent supporting by the programme.

\footnotetext{
${ }^{12}$ When interpreting these social value estimates it is important to note that similar caveats to the costeffectiveness estimates apply:

- The values reported are gross not net and they do not include an assessment of additionality as there is not sufficiently robust quantitative data to estimate it with any accuracy. It is likely to vary significantly by service user based on their initial 'distance' from the labour market.

- Benefits are only reported for one year: the majority of evaluation data does not extend beyond 12 months following the initial MIW intervention so it is not possible to estimate the extent to which benefits last beyond one year.
} 
- Overall social value: the total (gross) social value associated with lone parents reporting increased well-being on these three measures was £3.02 million; this equates to $£ 9$ per lone parent supporting by the programme. 


\section{Appendix 1: Additional Data Analysis}

Figure A: MIW employment outcomes by disability status

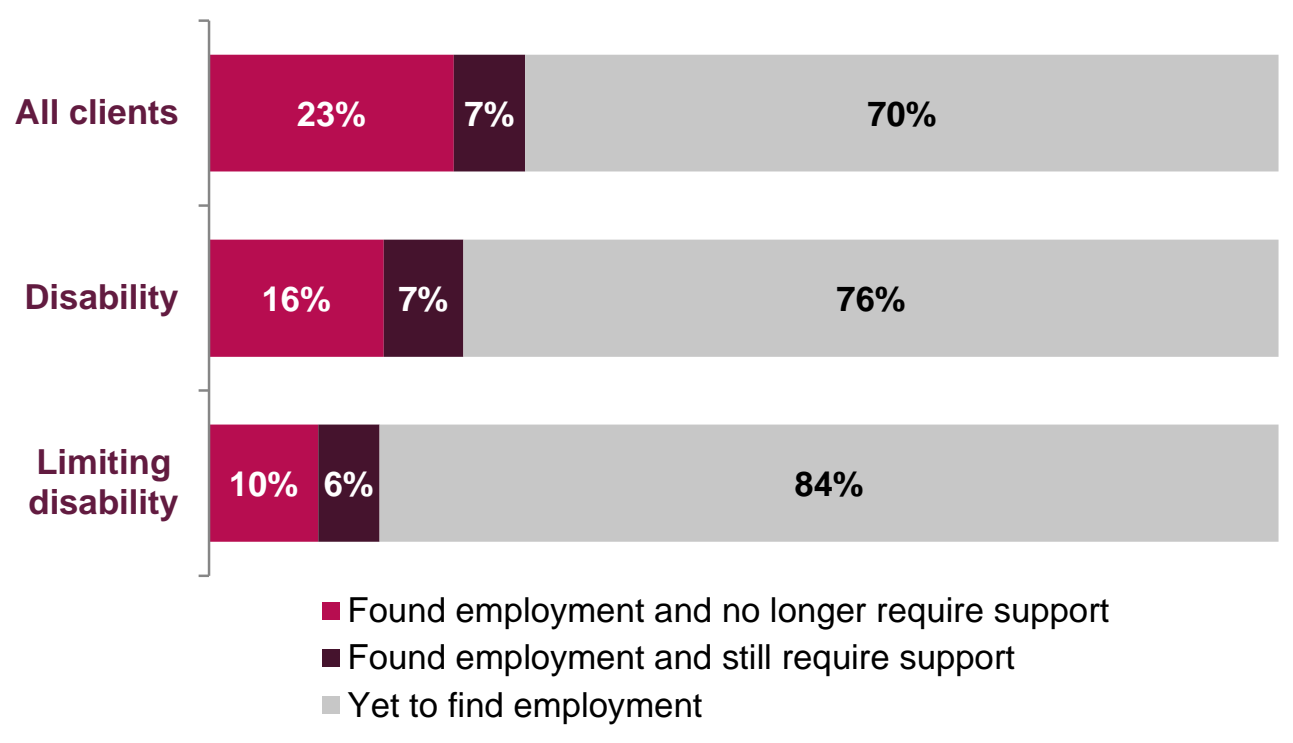

Source: Baseline and follow-up surveys of MIW clients

Base: 1,215 
Figure B: MIW employment outcomes by employment history and qualifications

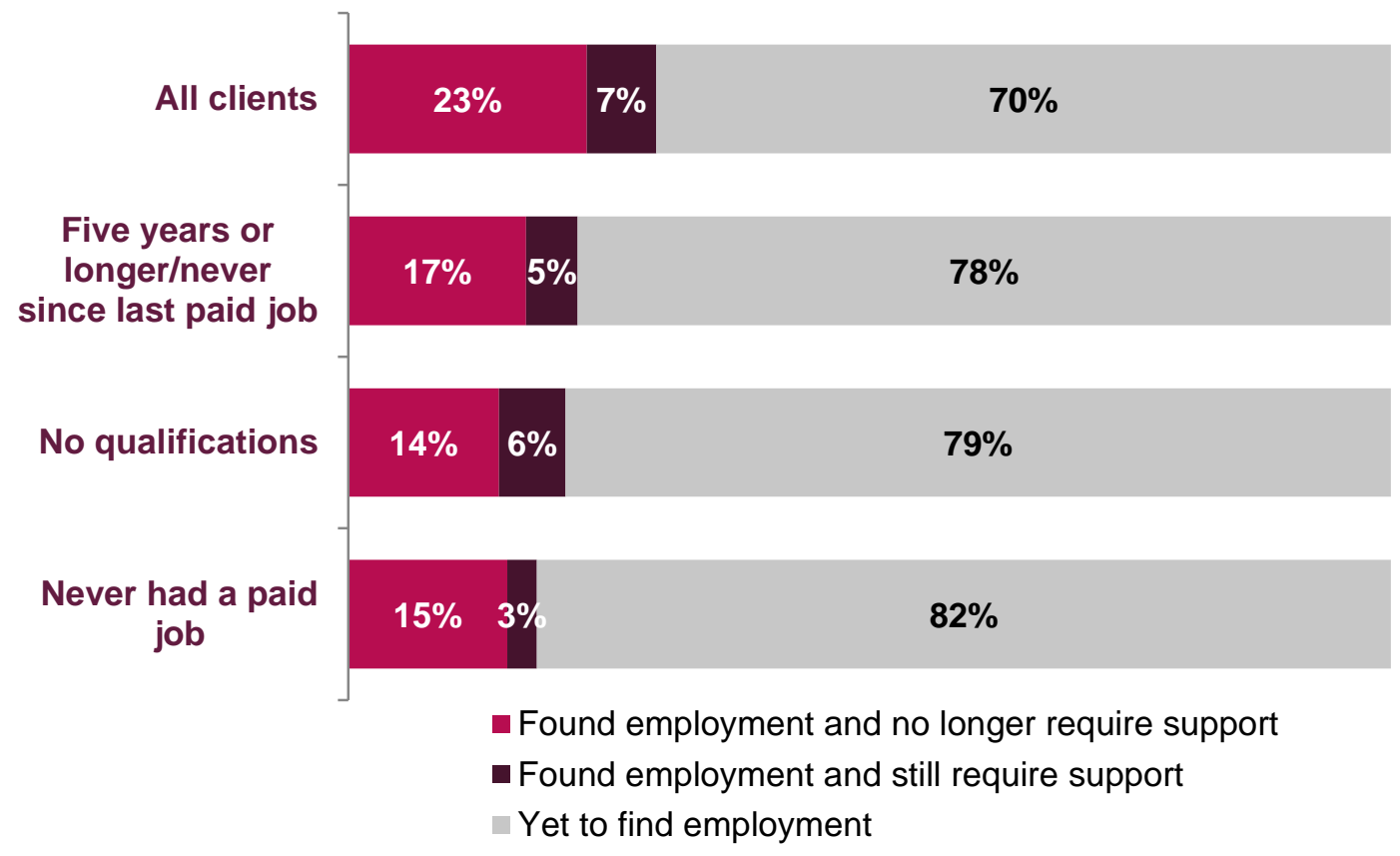

Source: Baseline and follow-up surveys of MIW clients Base: 1,215

Figure C: MIW employment outcomes by caring responsibilities

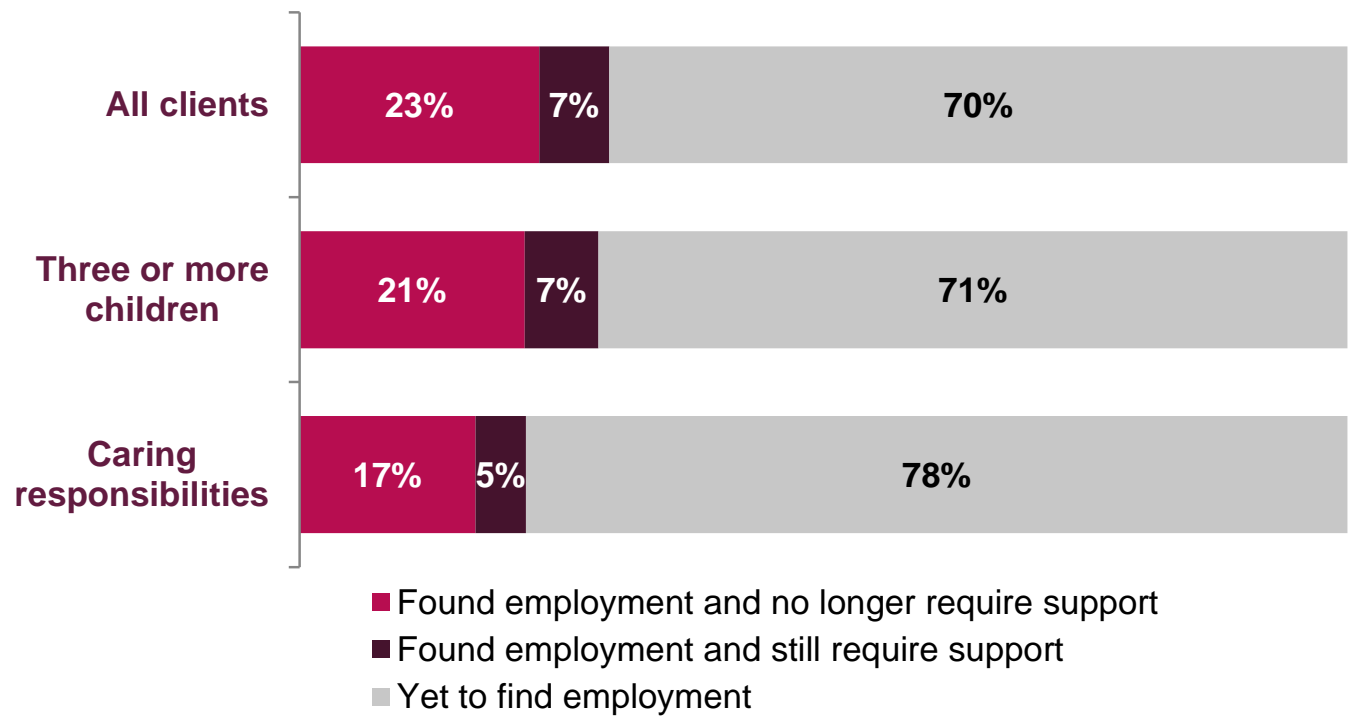

Source: Baseline and follow-up surveys of MIW clients

Base: 1,215 
Figure D: MIW employment outcomes by age of oldest child

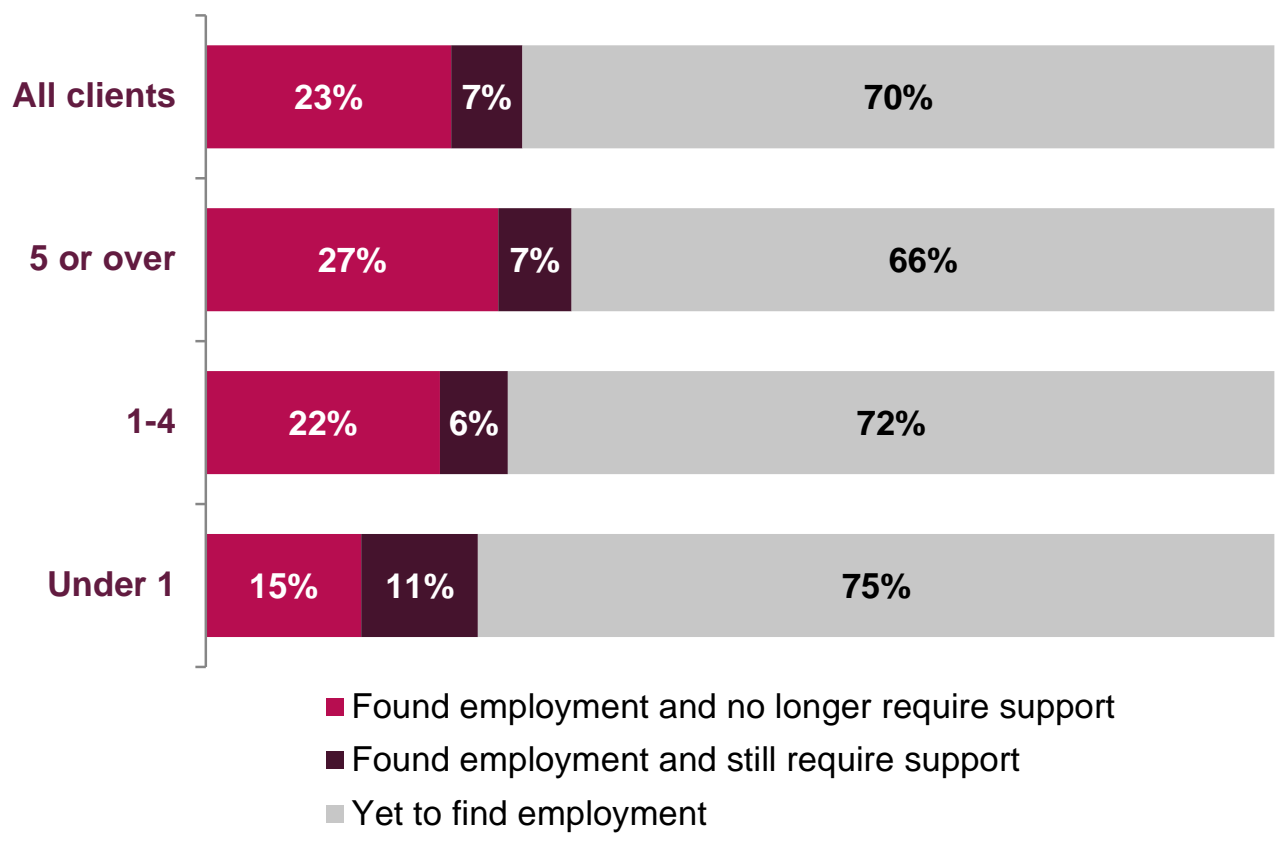

Source: Baseline and follow-up surveys of MIW clients

Base: 1,215

Figure E: MIW employment outcomes for clients with poor health and low well-being

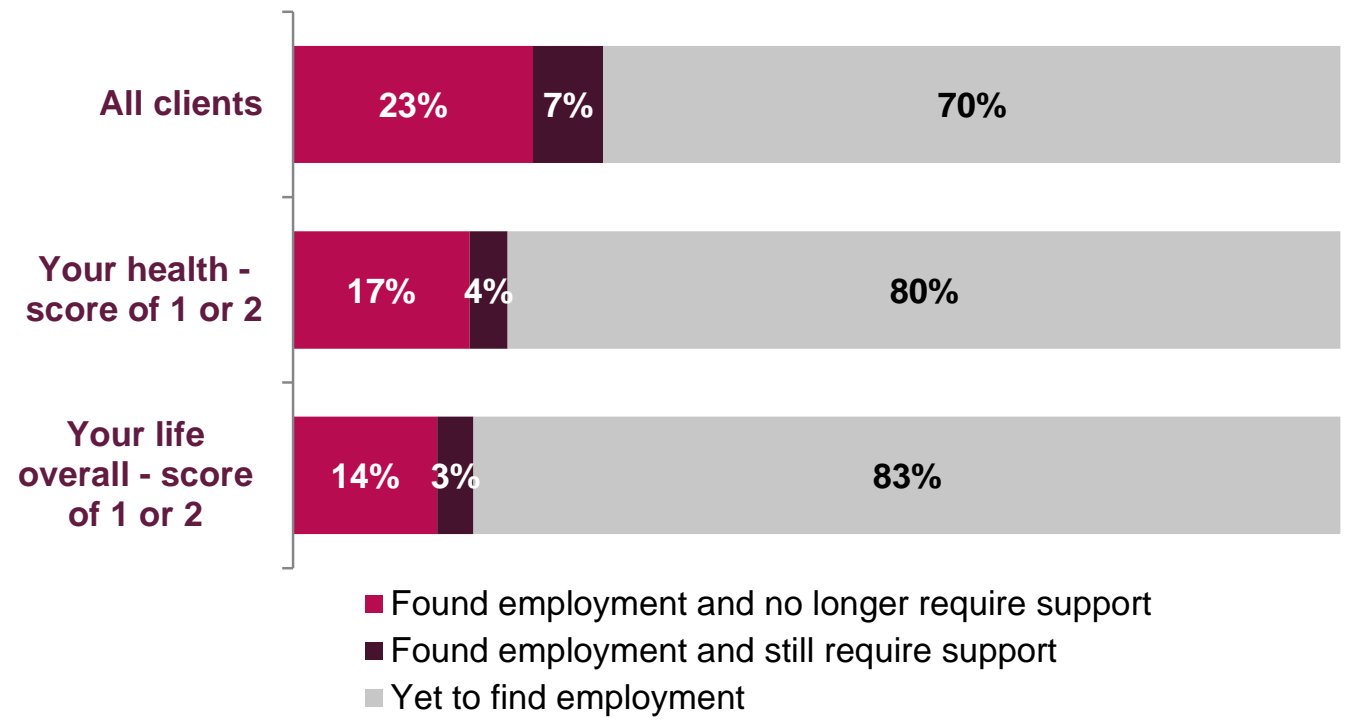

Source: Baseline and follow-up surveys of MIW clients

Base: 1,215 


\section{Appendix 2: Additionality considerations}

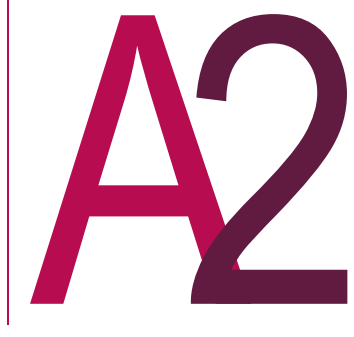

When assessing the value for money and impact of an intervention it is important to consider the principle of additionality: the extent to which the outcomes reported should be attributed to the intervention being evaluated. It involves considering three factors ${ }^{13}$ :

- Leakage: benefits to those outside of the spatial area or group which the intervention is intended to benefit.

- Deadweight: outcomes which would have occurred without intervention. Its scale can be estimated by assessing what would have happened in the 'do minimum' case

- Displacement and substitution: the extent to which the benefits of a project are offset by reductions of output or employment elsewhere.

We consider each of these in turn below.

\section{Leakage}

There will have been limited leakage from the Making it Work programme. Each partnership worked within very tight geographic and client group parameters, targeting out of and economically marginalised lone parents in their specific locality.

\section{Deadweight}

The evaluation design did not include a control or comparison group. As such assessment of deadweight relies on analysis and interpretation of qualitative evaluation data collected from partnerships, their stakeholders and service users in combination with the survey data already discussed.

The overall inference from the evaluation findings is that deadweight from the Making it Work programme is likely to have varied significantly for different types of clients across different types of outcomes. For employment outcomes, particularly those for lone parents closest to the labour market deadweight is likely to be relatively high. However, where employment outcomes have been achieved for lone parents distanced from the labour market deadweight is likely to be quite low. Similarly, for soft outcomes, including those associated with moving closer to the labour market, Making it Work interventions were much more important and additional, and deadweight therefore quite low.

\footnotetext{
${ }^{13}$ See: HM Treasury (2013). The Green Book: Appraisal and Evaluation in Central Government. P $52-45$
} 


\section{Displacement and substitution}

Making it Work did not aim to 'create' any new jobs, so when lone parents found work they did so at the expense of other labour market participants who were actively seeking work of a similar nature. As a result the substitution effects of Making it Work are likely to be relative high. These should be taken into account when the overall (net) impacts of the programme are considered. 


\section{Sheffield Hallam University}

Evaluation of Making It Work: an assessment of impact and value for money

DAYSON, Christopher <http://orcid.org/0000-0003-2402-1183>, PEARSON, Sarah <http://orcid.org/0000-0001-5049-5396> and SANDERSON, Elizabeth $<$ http://orcid.org/0000-0003-1423-1670>

Available from the Sheffield Hallam University Research Archive (SHURA) at:

http://shura.shu.ac.uk/18241/

\section{Copyright and re-use policy}

Please visit http://shura.shu.ac.uk/18241/ and http://shura.shu.ac.uk/information.html for further details about copyright and re-use permissions. 